\title{
REVITALISASI KEARIFAN LOKAL DAN NILAI KEISLAMAN DALAM PENGEMBANGAN POTENSI PARIWISATA SYARIAH
}

\author{
Miftahuddin \\ miftahuddin386@gmail.com \\ Fakultas Pascasarjana, Universitas Islam Negeri Sultan Syarif Kasim Riau
}

\begin{abstract}
This Research study is to see how deepth, the capability of Local Syariah Tourism at Siak Regency and toanalyseall factors influencing Syariah Tourism, such as reflection of Islamic values and local wisdom inside of Siak Cultures. The Method of this research was used a Qualitative Research and Library Research and the data obtained from observation at field directly. The Result of the Research expressed the wisdom of local syariah tourism at Siak Regency unknown and unfamiliar for visitor also Regency Government. It is influenced that the development of the local Syariah Tourism getting small attention from visitor and Goverment. It caused the local syariah tourism hard to get maximal target to create the destination of tourism which have aims to introduce the local syariah tourism to local visitor even all over the world. Based on interview result, the use of word "Syariah Tourism" is considered unaccustomed word and it doesn't have Selling Power Brand to attract the visitor to chooselocal syariah tourism as alternative tourism in local regency because it is considering just for moslem visitor not in general. The using Word "Syariah" have highest meaning and relate to Moslem Religion Culture and law.
\end{abstract}

Keywords: The Revitalization of local wisdom At Syariah Tourism

\begin{abstract}
Abstrak
Penelitian ini bertujuan untuk melihat bagaimana potensi pariwisata syariah di Kabupaten Siak, melihat faktor-faktor yang mempengaruhi pariwisata syariah dan melihat dampak nilai-nilai Islam dan Kearifan lokal di nilai-nilai Kebudayaan Siak. Metode yang dipakai dalam penelitian ini adalah Metode penelitian Kualitatif dengan Library Research dan observasi langsung kelapangan dengan menemui informan dan penelitian langsung ke objek penelitian. Hasil penelitian ini menunjukan bahwa kearifan lokal pariwisata syariah di kabupaten Siak masih dalam tahap proses yang panjang dan membutuhkan peran besar pemerintah, Pengembangan yang dilakukan dalam membangun destinasi pariwisata belum maksimal sehingga pengembangan yang telah dilakukan masih dalam skala dan jumlah terbatas, dari beberapa rangkaian hasil wawancara menunjukkan bahwa penggunaan istilah "Wisata Syariah" dinilai kurang tepat karena terkesan kaku dan kurang menjual untuk menjadi "Branding" pariwisata yang menyasar segmen wisatawan muslim. Penggunaan kata Syariah harus sangat hatihati karena berkaitan dengan pemberlakuan hukum Islam dalam kehidupan sehari-hari.
\end{abstract}

Kata Kunci: Revitalisasi Kearifan Lokal Pariwisata Syariah 


\section{PENDAHULUAN}

Studi tentang wisata Syariah ini berupaya mengeksplorasi makna pariwisata budaya yang diintegrasikan dengan wisata Syariah sebagai pengalaman spiritual masyarakat modern. Artinya, meskipun wisata Syariah ini termasuk bentuk pariwisata kontemporer sebagai fenomena modern, maka pada masyarakat sekuler para wisatawan nampak berupaya memenuhi beberapa kebutuhan spiritual.

Diyakini agama memainkan peran penting dalam pengembangan wisata selama berabad-abad dan telah mempengaruhi bagaimana orang memanfaatkan waktu luang. Peningkatan jumlah wisatawan dengan motivasi agama juga telah menarik perhatian akademisi, pemerintah dan lembaga pariwisata untuk mengembangkan pariwisata. ${ }^{1}$ Studi tersebut menunjukkan bahwa tujuan utama bagi sejumlah besar wisatawan agama terkait dengan kunjungan pada situs dari alkitab, Al-Quran atau teks-teks suci lain, atau dengan adanya spiritualisme, seperti mukjizat dan wahyu. ${ }^{2}$

Ada hubungan antara lembaga-lembaga agama dan pariwisata. Di satu sisi, wisata religi dapat diidentifikasi sebagai jenis tertentu pariwisata yang termotivasi baik sebagian atau secara eksklusif untuk alasan agama. seluruh perjalanan wisata mungkin memiliki tujuan agama, sedangkan kasus terakhir, kunjungan ke tempat keagamaan memiliki unsur multifungsi berupa sekedar perjalanan wisata.

Di sisi lain, pariwisata dapat dianggap identik sebagai agama. Dalam masyarakat sekuler modern, tidak hanya bebas memiliki (yaitu diskresi atau non kerja) waktu secara umum menjadi ruang untuk kontemplatif dan kreatif, kesatuan pemikiran dan tindakan, kesempatan bagi manusia untuk mengenali dan mengembangkan kebutuhan rohani mereka, tetapi juga pariwisata, sebagai penggunaan tertentu seperti waktu luang, telah datang untuk dilihat oleh sebagian orang sebagai perbuatan spiritual atau perjalanan suci. ${ }^{3}$

Perkembangan ekonomi Islam di dunia sungguh menggembirakan. Indonesia dianugerahi Sang Maha Pencipta kekayaan alam yang beragam, seperti laut, pantai, daratan, sungai, serta bangunan-bangunan peninggalan kebudayaan masa lampau.

\footnotetext{
${ }^{1}$ Kurniawan Gilang Widagdyo, 'Analisis Pasar Pariwisata Halal Indonesia', The Journal of Tauhidinomics, 2015.

${ }^{2}$ Kurniawan Gilang Widagdyo, 'Analisis Pasar Pariwisata Halal Di Indonesia', The Journal of Tauhidinomics, 2015.

${ }^{3}$ Alvien Septian Haerisma, 'Pengembangan Pariwisata Halal Di Indonesia Tinjauan Etika Bisnis Islam', Al-Mustashfa: Jurnal Penelitian Hukum Ekonomi Syariah, 2018 <https://doi.org/10.24235/jm.v3i2.3679>.
} 
Pemerintah semakin getol melakukan pembangun fisik atau infrastruktur, seperti jalan tol, jembatan, pelabuhan udara, pelabuhan laut, dan lain sebagainya. Indonesia sebagai Negara yang berpenduduk mayoritas Muslim, dalam konteks ekonomi dan bisnis syariah, sesungguhnya berpotensi mampu menjadi Negara terdepan dalam mengaplikasikan dan mengembangkannya.

Problem yang dihadapi Pemerintah sekarang adalah defisit anggaran belanja dan kualitas Sumber Daya Manusia (SDM) dibidang ekonomi syariah yang terbatas. Dapat diprediksi, ketika sumber-sumber pendapatan Negara tidak lagi mencukupi untuk membiayai pembangunan, maka langkah tradisional yang diambil Pemerintah adalah melakukan pinjaman luar negeri dan langkah cerdas Pemerintah dengan mengeluarkan kebijakan dibidang ekonomi berupa Amnesti Pajak, kendati kebijakan tersebut belum mampu membebaskan Negara dari belenggu utang.

Artinya, Pemerintah bersama masyarakat dalam kondisi ekonomi dan moneter seperti ini dituntut menciptakan sumber pendapatan baru selain yang telah disebutkan di atas. Hadirnya pariwisata syariah di dunia belum lama ini merupakan fenomena baru. ${ }^{4}$ Pariwisata di Indonesia tetap bertumbuh walaupun pertumbuhan perekonomian global terpuruk, pertumbuhan industri pariwisata di Indonesia tahun 2014 mencapai 9,39 persen lebih tinggi dari tahun sebelumnya. Angka itu diatas pertumbuhan ekonomi nasional yang mencapai 5,7 persen.

Hal tersebut sektor pariwisata harusnya mendapatkan perhatian dan dikelola agar dapat terus menyumbang bagi pendapatan bagi daerah. Pembangunan pariwisata memiliki arti yang sangat penting ditinjau dari berbagai aspek. Dari sisi ekonomi pariwisata, dalam beberapa tahun terakhir sektor pariwisata memberikan kontribusi terhadap PDB, (baik melalui devisa maupun perputaran ekonomi), dapat membuka peluang usaha jasa pariwisata baik langsung maupun tidak langsung), dan membuka peluang kerja yang sangat banyak.

Seiring dengan objek wisata yang ada, kearifan lokal di kabupetan siak merupakan salah satu potensi untuk mendatangkan wisatawan ke kabupaten siak. Tradisi makan sirih merupakan warisan budaya masa silam yang merupakan salah satu kearifan lokal di kabupaten siak. lebih dari 3000 tahun yang lampau atau di zaman Neolitik, hingga saat ini. Budaya makan sirih hidup di Asia Tenggara. Pendukung budaya

\footnotetext{
${ }^{4}$ Aan Jaelani, Edy Setyawan, and . Nursyamsudin, 'Religi, Budaya Dan Ekonomi Kreatif: Prospek Dan Pengembangan Pariwisata Halal Di Cirebon', Al-Mustashfa: Jurnal Penelitian Hukum Ekonomi Syariah, 2017 <https://doi.org/10.24235/jm.v2i2.2152>.
} 
ini terdiri dari berbagai golongan, meliputi masyarakat bawah, pembesar negara, serta kalangan istana. Tradisi makan sirih tidak diketahui secara pasti dari mana berasal.

Kebudayaan melayu juga terdapat pengaruh dari luar, tetapi tidak mengubah struktur dasar kebudayaan tersebut. Kelenturan ini terlihat pada struktur dan keterbukaan stuktur bahasa yang dalam prosesnya banyak menyerap kosakata dari berbagai bangsa. Sehingga bahasa melayu khususnya riau tidak saja digolongkan sebagai bahasa lingua franca, tetapi juga digunakan oleh kalangan cendikiawan melayu.

Kebudayaan melayu yang terbuka, akomodatif dan adaptif dengan sistem nilai agama, adat dan tradisi yang dikandungnya. Telah teruji kemampuanya dalam membangkitkan semangat penyertaan masyarakat pendukungnya dalam pembangunan bangsa. Karena itu, nilai-nilai itu dirasa perlu untuk dipelihara serta ditumbuh kembangkan dan disosialisasikan guna memacu pertumbuhan masyarakat, terutama dibidang ekonomi dan sumber daya manusia. ${ }^{5}$

Dalam sejarahnya Masyarakat Siak sebagai Bangsa Melayu adalah masyarakat yang terbuka, hal ini disebabkan oleh matra pencaharian mereka yang bersumber dari laut, sungai dan alam sekitarnya sehingga mereka memilih membuat kampung bahkan ibukota kerajaan ditepi laut. Akibatnya semua pengaruh dunia seperti agama, budaya, sosial-politik, dan ekonomi dunia mempengaruhi budaya bangsa melayu tersebut.

Sejak dahulu kala, manusia melayu membina budayanya sendiri hingga menjadi mencapai tahap tamaddun yang tinggi, yang telah memberi sumbangan terhadap budaya (Culture) dan tamaddun (Civilitiation) dunia. Hasil ciptaan alam melayu memperlihatkan corak yang cukup halus sifatnya, cukup matang pengolahannya, dan cukup tinggi daya fikirannya. Hasil ciptaan budaya melayu memperlihatkan corak yang cukup halus sifatnya, cukup matang pengolahannya.

Kebudayaan melayu begitu identik dengan nilai-nilai islam, hal ini termaktub dalam karifan lokal dari masyarakt melayu itu sendiri, khususnya masyarakat dikabupaten Siak, hal ini terlihat dari representasi dari keberadaan ikon-ikon kebudayaan, salah satu contoh adalah rumah adat itu sendiri. Didalam budaya melayu sendiri dikenal adanya "Rumah Balai" yang merupakan semua bangunan yang digunakan untuk pertemuan anggota masyarakat, seperti balai adat, balai penghadapan, balairung sari, balai panca persada, balai kerapatan, dan sebagainya.

\footnotetext{
${ }^{5}$ Aan Jaelani, 'Halal Tourism Industry in Indonesia: Potential and Prospects', SSRN Electronic Journal, $2017<$ https://doi.org/10.2139/ssrn.2899864>.
} 


\section{METODOLOGI PENELITIAN}

Penelitian ini merupakan Penelitian kualitatif bersifat deskriptif yaitu Penelitian yang berusaha untuk mendeskripsikan suatu objek atau fenomena secara naratif. Data maupun fakta yang dihimpun penulis berupa kata, gambar atau dokumen yang berisi kutipan-kutipan dari data atau fakta yang telah diungkap di lokasi penulisan dan selanjutnya penulis memberikan ilustrasi yang utuh untuk memberikan dukungan terhadap data yang disajikan. Jadi dalam pendekatan dalam penulisan ini adalah kualitatif deskriptif yang menjelaskan tentang objek yang diteliti adalah revitalisasi kearifan lokal dan nilai-nilai keislaman dalam pengembangan potensi pariwisata syariah di kabupaten Siak. 6

Penelitian ini dilakukan di Kabupaten Siak, tepatnya di objek wisata yang berada di Kabupaten Siak yang menjadi destinasi wisata populer saat Pemilihan lokasi ini sebagai lokasi penelitian dengan alasan karena objek wisata cukup populer di Kabupaten Siak dan sedang banyak diminati oleh wisatawan domestik maupun luar daerah atau bahkan luar negeri. Adapun penelitian ini dilakukan dimulai pada bulan Oktober 2019 sampai dengan selesai.

Dalam penelitian ini sumber data yang digunakan adalah data primer dan data sekunder yaitu data yang diambil dan dikumpulkan berdasarkan data di lapangan yang diambil dengan menggunakan kuisioner/angket yang disebarkan kepada sampel yang dipilih dan kemudian diolah. Kemudian disamping itu penelitian ini juga menggunakan data sekunder, yaitunya data yang diperoleh secara tidak langsung dari sumbernya, seperti data-data yang telah dipublikasikan di media massa ataupun media online serta data-data yang diperoleh dari instansi pemerintah dan dinas-dinas terkait seperti Badan Pusat Statistik, Dinas Pariwisata Daerah dan lainnya.

\section{HASIL DAN PEMBAHASAN}

\section{Faktor-Faktor yang Mempengaruhi Pariwisata Syariah di Kabupaten Siak}

Berdasarkan hasil pengamatan penulis, pengembangan pariwisata di Kabupaten Siak, dimana pemerintah Kabupaten Siak telah melakukan upaya pengembangan ataupun promosi yang dilakukan untuk memasarkan potensi wisata yang ada di Kabupaten Siak. Akan tetapi pengembangan yang dilakukan dalam membangun

${ }^{6}$ BPS Kabupaten Siak, 'Analisis Kesiapan Destinasi Dalam Rangka Pencapaian Target 20 Juta Wisman Pada Tahun 2019 2015', 2019, 1-51. 
destinasti pariwisata belumlah maksimal sehingga pengembangan yang telah dilakukan masih dalam skala dan jumlah terbatas.

Objek wisata yang ada di Kabupaten Siak adalah inventarisasi dari Dinas Pariwisata, Pemuda dan Olahraga. Akan tetapi dari semua objek pariwisata sejarah yang ada di Kabupaten Siak hanya beberapa objek wisata yang baru dikembangkan oleh pemerintah daerah, salah satunya yaitu Istana Siak. Sementara itu menyangkut soal pengembangan pariwisata yang ada di Kabupaten Siak yang bertanggung jawab yaitu Disparpora Kabupaten Siak, berikut diuraikan tugas dan fungsi Dinas Pariwisata, Pemuda, dan Olahraga Kabupaten Siak berdasarkan Peraturan Bupati Kabupaten Siak Nomor 53 Tahun 2012 sebagai berikut: ${ }^{7}$

1. Dinas Pariwisata, Pemuda dan Olahraga mempunyai tugas pokok melaksanakan urusan pemerintahan daerah berdasarkan azas otonomi dan tugas pembantuan di bidang pariwisata, pemuda dan olahraga.

2. Dinas Pariwisata, Pemuda dan Olahraga dalam melaksanakan Tugas menyelenggarakan fungsi:

a) Perumusan kebijakan teknis dibidang pariwisata, pemuda dan olahraga;

b) Penyelenggaraan pelayanan umum dibidang pariwisata, pemuda dan olahraga;

c) Pembinaan pelaksanaan tugas dibidang pariwisata, pemuda dan olahraga;

d) Pelaksanaan urusan tata usaha dinas;

e) Pelaksanaan tugas yang diberikan oleh Bupati sesuai dengan tugas dan fungsinya.

Adapun upaya yang telah dilakukan oleh Dinas Pariwisata, Pemuda dan Olahraga dalam pengembangan pariwisata di Kabupaten Siak, yaitu dengan melalui promosi dan melakukan berbagai event yang telah dijadikan kegiatan tahunan oleh Dinas Pariwisata, Pemuda dan Olahraga.

Upaya dalam pengembangan potensi wisata di Kabupaten Siak selama ini belum maksimal dan menyeluruh, akibatnya keberadaan kegiatan kepariwisataan di Kabupaten Siak belum dapat dinikmati. Biarpun dalam berbagai hal masih banyak kekurangan, perkembangan kegiatan pariwisata tersebut selama ini sedikit banyak telah mendorong perkembangan ekonomi, sosial dan budaya. Perencanaan yang terpadu untuk

${ }^{7}$ Dinas Pendidikan dan Kebudayaan Provinsi Riau, Direktori Budaya Melayu Riau (Pekanbaru: Dinas Pendidikan dan Kebudayaan Provinsi Riau, 2015). 
mengantisipasi perkembangan kegiatan kepariwisataan yang cenderung bergerak cepat perlu didasari oleh data, keterangan dan fakta yang kuat seperti keindahan, kelestarian, pasar dan keseimbangan antara keaslian kawasan dengan penambahan fasilitas baru yang sesuai konteks.

Mewujudkan konsep perencanaan yang terpadu terhadap potensi-potensi pariwisata yang ada serta tidak terbatasnya pada rencana yang bersifat konseptual, maka inventarisasi potensi pariwisata di Kabupaten Siak perlu dilakukan secara cermat dan teliti dengan pembahasan yang detail, mendalam dan bersifat operasional serta mencakup permasalahan yang bersifat teknis dengan pendekatan multi disiplin, multipersonal dan multidimensi sehingga pada akhirnya kualitas kawasan dan objekobjek wisata di dalamnya dapat ditingkatkan.

Pengembangan pariwisata yang dilakukan oleh Dinas Pariwisata, Pemuda dan Olahraga juga telah melakukan banyak hal, terbukti dengan terbinanya dua desa wisata yang telah terbentuk dari tahun 2012 dan diharapkan desa tersebut dapat memotivasi masyarakat akan potensi pariwisata yang ada di Kabupaten Siak. ${ }^{8}$

Dalam strategi pengembangan pariwisata dan kebijakan, otoritas yang bertanggung jawab harus mempertimbangkan pandangan dari sejumlah pemangku kepentingan pemerintah, swasta, masyarakat, serta kelompok khusus yang memiliki kepentingan. Pelibatan stakeholder dalam perumusan strategi pengembangan pariwisata yang berkelanjutan dan kebijakan mungkin menjadi hal yang sangat penting untuk diperhatikan.

Sebuah keharusan mengakomodasikan seluruh masukan atau pendapat dari berbagai kelompok pemangku kepentingan dalam hal identifikasi masalah, legitimasi, keterlibatan dan resolusi konflik. Kerangka stakeholder telah diterapkan dalam hubungannya dengan siklus hidup daerah tujuan wisata dalam rangka menganalisis sikap terhadap pemangku kepentingan pariwisata dan pembangunan berkelanjutan.

Berbagai promosi yang telah disampaikan oleh Kepala Bidang Pengembangan dan Promosi Pariwisata Kabupaten Siak bentuk program tersebut adalah berbagai upaya yang telah dilakukan oleh Dinas Pariwisata dalam pengembangan pariwisata dengan mempromosikan potensi-potensi objek wisata dan budaya dalam bentuk media,

${ }^{8}$ Biro Administrasi Perekonomian Pemerintah Provinsi Riau, Riau Business Guide (Pekanbaru: Biro Administrasi Perekonomian Pemerintah Provinsi Riau, 2015). 
sehingga masyarakat lokal maupun mancanegara dapat mengetahui informasi akan kepariwisataan yang ada di Kabupaten Siak.

Adapun pembangunan gedung pasar seni yang dilakukan oleh Dinas Pariwisata Pemuda dan Olahraga untuk mempermudah para pengrajin menjajakan hasil karyanya sebagai oleh-oleh bagi wisatawan, pembangunan ini dimulai pada tahun 2013-2014. Pemerintah daerah berharap gedung pasar seni tersebut berada sangat strategis di Kabupaten Siak, yang berada ditengah kota dan berada dekat dengan kompleks Istana Siak.

Dari beberapa rangkaian hasil wawancara menunjukkan bahwa penggunaan istilah "Wisata Syariah" dinilai kurang tepat karena terkesan kaku dan kurang menjual untuk menjadi "Branding" pariwisata yang menyasar segmen wisatawan muslim. Penggunaan kata Syariah harus sangat hati-hati karena berkaitan dengan pemberlakuan hukum Islam dalam kehidupan sehari-hari.

Hal ini berlaku juga dalam praktik bisnis pariwisata. Apabila bisnis pariwisata yang dijalankan berlandaskan Syariah maka harus sungguh-sungguh menegakkan hukum Islam. Penggunaan istilah "wisata Syariah" atau Syariah Tourism dinilai lebih tepat karena lebih spesifik terhadap kebutuhan-kebutuhan wisatawan muslim seperti kebutuhan akan sarana beribadah dan kebutuhan akan makanan dan minuman Syariah.

Istilah Syariah lebih disetujui karena langsung mengacu pada produk/jasa dalam bisnis pariwisata seperti: Syariah food, Syariah restoran, Syariah destination dan produk-produk pariwisata lainnya. Istilah Syariah jelas menyasar wisatawan muslim sebagai pasar utama.

Di Kabupaten Siak hanya terdapat sedikit unit usaha biro perjalanan wisata atau tours and travel. Dari jumlah tersebut, belum terdapat BPW (tours and travel) yang menyediakan paket perjalanan/wisata yang sesuai dengan kriteria pariwisata Syariah, atau telah memiliki daftar akomodasi dan restoran yang sesuai kriteria Syariah. Untuk pramuwisata juga belum terdapat pramuwisata (tour guide) yang khusus untuk menghandle tamu atau wisatawan muslim.

Demikian pula untuk Biro Perjalanan Wisata (BPW) dan Pramuwisata, semua masih bersifat konvensional dan belum ada yang dikhususkan untuk melayani wisatawan muslim. Jika ingin mengembangkan Kabupaten Siak menjadi destinasi wisata Syariah, maka pemerintah harus dapat mendorong BPW di Kabupaten Siak dan sekitarnya untuk membuat paket-paket wisata Syariah atau Syariah. 
Dalam prakteknya peran BPW sangat besar untuk mendatangkan wisatawan muslim baik nusantara maupun mancanegara. Jaminan wisata Syariah atau Syariah lebih kuat melalui paket-paket wisata, karena segala sesuatunya sudah disusun dengan baik oleh BPW, destinasi, daya tarik, hotel, dan resoran yang bersifat family friendly, sehingga wisatawan muslim terutama yang berpergian bersama keluarga dapat terhindar dari hal-hal yang dilarang oleh aturan agama Islam.

\section{Dampak Nilai-Nilai Keislaman dan Kearifan Lokal Terhadap Pariwisata Syariah di Kabupaten Siak}

Dalam melakukan branding Dinas Pariwisata tidak ada menggunakan endorse melalui pihak manapun. mereka masih melakukan branding secara mandiri yaitu melalui media cetak, digital, sosial, event kapariwisataan, instansi pemerintahan dan juga masyarakat setempat yang sadar wisata. Kemudian Dinas Pariwisata menggandeng Bujang Dara Siak yang terbaik di tingkat Kabupaten, Provinsi maupun Nasional dalam melakukan promosi pariwisata yang ada di Siak yang tentunya tak lepas pula untuk mempromosikan brand "Siak The Truly Malay".

Siak kota "Istana" "Matahari Timur" itulah sebutan dari Kabupaten Siak, kabupaten yang berdiri tahun 1999 lalu merupakan pecahan dari kabupaten bengkalis. Kabupaten Siak begitu banyak menyimpan berbagai objek wisata yang sangat menarik untuk dikunjungi, mulai dari wisata sejarah, seni, budaya, religious, serta alam yang bergitu asri untuk dipandang.

Istana Siak peninggalan sejarah yang bisa di kunjungi di Kabupaten Siak seperti tangsi belanda, balai kerapatan tinggi, makam Sultan Koto Tinggi, Makam Sultan Syarif Kasim, makam Raja kecik, dan makam puteri Kaca Mayang. Selain wisata sejarah, wisata alam, dan buatan Kabupaten Siak juga memiliki destinasi budaya seperti kesenian Melayu, adat, hidangan khas melayu, permainan dan kebiasaan kehidupan masyarakat melayu sehingga Siak layak untuk dikenalkan sebagai “Siak The Truly Malay” yang artinya Siak adalah Melayu yang sebenarnya.

Kemudian kalimat "Siak The Truly Malay" tentunya memiliki makna yang sangat mudah untuk dipahami bahwasannya siak itu adalah daerah Melayu yang sebenarnya dan segala bentuk peradaban melayu ada di kota siak. Tidak lupa pula variasi warna yang di tampilkan pada daun sirih dan juga pada kalimat atau tagline "Siak The Truly Malay" juga dipilih karena warna tersebut merupakan lambang kebesaran kerajaan 
Melayu dari dahulu hingga sekarang. Jadi sangat jelas jika kita hanya melihat dari brandnya saja, khalayak akan tahu bahwa identitas kota siak yang tergambar dari brand tersebut adalah identitas Melayu.

Dinas Pariwisata Siak selaku Leading Sector adalah pihak yang paling bertanggung jawab dalam melakukan branding Siak The Truly Malay. Kemudian tak lepas juga dari perhatian pemda dan seluruh instansi pemerintahan setempat karena brand ini merupakan kebijakan pemerintahan. Dinas pariwisata juga menggaet Bujang Dara Kabupaten Siak dalam melakukan branding daerah.

Dalam konteks pencitraan kota slogan dan visi kota dapat dipahami sebagai the wish image (citra harapan), citra yang diharapkan dapat diwujudkan dan dimiliki oleh kota tersebut. Bagi kota Siak, slogan atau brand "Siak The Truly Malay" merupakan brand yang dibuat untuk membentuk citra Kota Siak, yaitu menjadikan Siak sebagai Jiwanya Melayu.

Dalam sistem kebudayaan siak yang menyangkut dengan kearifan lokal, dalam wawancara dengan tokoh adat melayu Siak, beliau mengemukakan bahwa kerajaan Siak adalah pusat pemerintahan yang dipimpin oleh seorang Sultan dengan orang-orang besarnya, sehingga yang dilakukan dalam acara adat mempunyai sopan santun yang telah diatur oleh Kerajaan dan Datuk-datuk dari Ketua Suku. Setiap pelanggaran adat dan sopan santun oleh rakyatnya akan mendapat hukuman atau sanksi yang sesuai dengan pelanggarannya. Didalam adat kerajaan siak ada beberapa aturan yaitu : ${ }^{9}$

1. Adat Sebenar Adat

Yang dimaksud dengan "adat sebenar adat" adalah prinsip adat Melayu yang tidak dapat diubah-ubah. Prinsip tersebut tersimpul dalam "adat bersendikan syarak". Ketentuan-ketentuan adat yang bertentangan dengan hukum syarak tidak boleh dipakai lagi dan hukum syaraklah yang dominan, hal ini telah disabdakan oleh Sultan Siak Raja Kecik sewaktu beliau dinobatkan.

2. Adat yang diadatkan

Adat ini adalah adat yang dibuat oleh Kerajaan Siak oleh Sultan yang sedang berkuasa sebagai pemimpin pemerintahan di negeri Siak bersama Dewan Datuk sebagi penasehat Sultan pada kurun waktu tertentu dan masa berlakunya adat yang diadatkan ini ialah sepanjang belum dirubah oleh penguasa berikutnya atau Sultan penggantinya.

${ }^{9}$ Dinas Pendidikan dan Kebudayaan Provinsi Riau. Tahun 20019 


\section{Adat yang Teradat}

Adat ini adalah adat yang disusun bersama oleh Datuk-datuk kepala suku dengan pemuka-pemuka dinegeri Siak pada masa kerajaan dahulu sejak berdirinya Kerajaan Gasib sampai Kerajaan Siak yang dipimpin oleh Raja Kecik. Adat ini turun temurun dalam masyarakat melayu siak yang telah lama mentradisi dan sudah menjadi pegangan bersama yang harus ditaati oleh rakyat siak.

\section{Perkembangan Pariwisata Syariah di Kabupaten Siak (Hasil Temuan, Harapan dan Kenyataan)}

Dalam mengukur kinerja implementasi suatu kebijakan publik harus memperhatikan indikator kebijakan, organisasi dan lingkungan. Perhatian itu perlu darahkan karena melalui pemilihan kebijakan yang tepat maka masyarakat dapat berpartisipasi memberikan kontibusi yang optimal untuk mencapai tujuan yang diinginkan. Selanjutnya, ketika sudah ditemukan kebijakan yang terpilih diperlukan organisasi pelaksana, karena di dalam organisasi ada kewenangan dan berbagai sumber daya yang mendukung pelaksanaan kebijakan bagi pelayanan publik.

Faktor Pendukung Faktor pendukung adalah faktor penentu keberhasilan suatu kebijakan. Dalam konteks pengembangan pariwisata di Kabupaten Siak yang menjadi kekuatan Dinas Pariwisata, Pemuda dan Olahraga dalam menjalankan program kerja adalah:

a) Potensi Pariwisata Untuk Menggantikan Potensi Alam Sebagai Potensi Andalan Kabupaten Siak termasuk salah satu daerah penghasil minyak di Indonesia, Kabupaten Siak setiap tahunnya mendapatkan dana perimbangan yang relatif besar, besarnya dana perimbangan yang diterima membuat anggaran pendapatan dan belanja daerah (APBD) Kabupaten Siak termasuk terbesar kedua di Riau setelah Kabupaten Bengkalis.

b) Potensi Pariwisata Sebagai Penggerak Ekonomi Masyarakat. Pariwisata sebagai suatu sektor kehidupan, telah mengambil peran penting dalam Pembangunan Perekonomian bangsa-bangsa di dunia, khusunya dalam dua (2) dekade terakhir, yang ditunjukkan dengan meningkatnya kesejahteraan ekonomi bangsa-bangsa didunia yang semakin baik dan maju. Kemajuan dan kesejahteraan yang makin tinggi telah menajdikan pariwisata sebagai bagian pokok dari kebutuhan atau gaya hidup manusia dan menggerakkan jutaan manusia untuk mengenal alam 
dan budaya kebelahan atau kawasan-kawasan dunia lainnya. Kelembagaan Dinas Pariwisata, Pemuda dan Olahraga Otonomi daerah memberikan otoritas kepada pemerintah setempat untuk menggali potensi daerahnya. Pariwisata menjadi potensi untuk dikembangkan di Kabupaten Siak

c) Kelembagaan Dinas Pariwisata, Pemuda dan Olahraga berperan besar dalam menggali potensi pariwisata sebagai penggerak ekonomi masyarakat. Inisiatif daerah untuk membuat kebijakan yang sesuai dengan konteks kebutuhan daerahnya. Seperti kebijakan Pemerintah Kabupaten Siak melalui Dinas Pariwisata, Pemuda dan Olahraga yang berkomitmen untuk mengembangkan pariwisata Kabupaten Siak dan menjadikan Kabupaten Siak sebagai daerah tujuan wisata di Provinsi Riau.

\section{KESIMPULAN}

Potensi Pariwisata Syariah di Kabupaten Siak pada dasarnya memiliki prospek ekonomi yang baik sebagai bagian dari industri Pariwisata Daerah dan Nasional khususnya dibidang industri Pariwisata Syariah. Kabupaten siak memiliki prospek yang bagus untuk maju menjadi destinasi wisata yang menarik bagi para wisatawan dalam negeri maupun mancanegara.

Industri wisata ini bertujuan bukan hanya memberikan aspek material dan psikologis bagi wisatawan itu sendiri, melainkan juga memiliki kontribusi dalam peningkatan pendapatan pemerintah. Wisata halal ini tidak besifat ekslusif, namun inklusif bagi semua wisatawan (Muslim dan Non Muslim).

Dari hasil penelitian baik dengan wawancara maupun observasi langsung kelapangan dengan cara menemui informan-informan terkait seperti tokoh masyarakat, tokoh adat, tokoh agama, pelauk industri kreatif dan tradisional maupun pengunjung sekitar untuk menggali dan menelusuri lebih jauh tentang industri dan perkembangan pariwisata Syariah di Kabupaten Siak, ditemukan beberapa faktor yang mempengaruhi pariwisata Syariah di Kabupaten Siak : Ketersediaan infrastruktur merupakan salah satu faktor yang mempengaruhi industri pariwisata halal di Kabupaten Siak, seperti keberadaan hotel, restoran dan akses jalan yang layak dan nyaman menuju lokasi objek wisata, factor yang kedua adalah sajian atraksi-atraksi budaya lokal dan hasil kerajinan tradisional setempat, faktor ini sangat mempengaruhi minat pengunjung dalam mengunjungi objek wisata ini, mengingat mindset dari pengunjung yang datang ke 
kabupaten siak adalah berwisata sejarah bukanlah pariwisata kontemporer. Ketersediaan faktor penunjang seperti rumah makan, penginapan dan tempat-tempat kuliner lainya menjadi salah satu faktor yang berpengaruh terhadap keberlangsungan pariwisata Syariah di Kabupaten Siak.

Tradisi merupakan warisan budaya dan kental dengan nilai-nilai kesilaman dan dapat dijadikan pilihan wisata budaya di Kabupaten Siak hal tersebut tentunya menimbulkan dampak bagi kunjungan wisatawan dan diharapkan dengan menjadikan tradisi tersebut sebagai wisata budaya handal di Kabupaten Siak dan dapat melestarikan kebudayaan yang ada di Kabupaten Siak.

Kearifan lokal masyarakat di Kabupten Siak masih perlu kembali dikembangkan dan digali, sehingga nilai-nilai kearifan lokal yang erat dengan nilai-nilai keislaman yang dianut masyarakat setempat yang bisa dieksplor dan ditonjolkan menjadi lebih baik dan dikemas sedemikain rupa untuk disajikan sebagai sebuah destinasi wisata yang modern namun tidak menghilangkan nilai-nilai luhurnya, nilai-nilai seperti ini masih minim di gali dan perlu kerjasama dengan berbagai pihak terkait, seperti pemerintah dengan organisasi-organisasi di masyarakat, tercipta sinergitas dan menjadi lebih baik kedepan.

\section{DAFTAR PUSTAKA}

Biro Administrasi Perekonomian Pemerintah Provinsi Riau, Riau Business Guide (Pekanbaru: Biro Administrasi Perekonomian Pemerintah Provinsi Riau, 2015)

BPS Kabupaten Siak, 'Analisis Kesiapan Destinasi Dalam Rangka Pencapaian Target 20 Juta Wisman Pada Tahun 2019 2015', 2019, 1-51

Dewantara, G. A. H., \& Astuti, P, 'Kajian Implementasi Program Revitalisasi Kawasan Kota Lama Sebagai Kawasan Pariwisata', Journal of Politic and Government Studies, 6.4 (2017), 41-50

Dinas Pendidikan dan Kebudayaan Provinsi Riau, Direktori Budaya Melayu Riau (Pekanbaru: Dinas Pendidikan dan Kebudayaan Provinsi Riau, 2015)

Gilang Widagdyo, Kurniawan, 'Analisis Pasar Pariwisata Halal Indonesia', The Journal of Tauhidinomics, 2015

Haerisma, Alvien Septian, 'Pengembangan Pariwisata Halal Di Indonesia Tinjauan Etika

Bisnis Islam', Al-Mustashfa: Jurnal Penelitian Hukum Ekonomi Syariah, 2018 <https://doi.org/10.24235/jm.v3i2.3679> 
Jaelani, Aan, 'Halal Tourism Industry in Indonesia: Potential and Prospects', SSRN Electronic Journal, 2017 <https://doi.org/10.2139/ssrn.2899864>

Jaelani, Aan, Edy Setyawan, and . Nursyamsudin, 'Religi, Budaya Dan Ekonomi Kreatif: Prospek Dan Pengembangan Pariwisata Halal Di Cirebon', Al-Mustashfa: Jurnal Penelitian Hukum Ekonomi Syariah, 2017

<https://doi.org/10.24235/jm.v2i2.2152>

Kementrian Pariwisata Republik Indonesia, KAJIAN PENGEMBANGAN WISATA SYARIAH, 2015

Tenas Effendy, Tunjuk Ajar Melayu (Pekanbaru: Melayu, Dinas Pendidikan dan Kebudayaan Pemerintah Provinsi Riau, 2015)

Thamrin, Husni, 'Revitalisasi Nilai-Nilai Kearifan Lingkungan (Pendekatan Ecoculture Tentang Arti Penting Tanah Adat Dalam Pelestarian Lingkungan Hidup Di Kabupaten Rokan Hilir Provinsi Riau)’ (Universitas Riau, 2015)

Widagdyo, Kurniawan Gilang, 'Analisis Pasar Pariwisata Halal Di Indonesia', The Journal of Tauhidinomics, 2015

Zulfikar MS, Kaffahisme Ideologi Ekonomi Masa Depan (Jakarta: Kompas Gramedia, 2014) 